\title{
Stent thrombosis rates the first year and beyond with new- and old- generation drug-eluting stents compared to bare metal stents
}

\author{
Christoph Varenhorst ${ }^{1,2}$ (1) Martin Lindholm ${ }^{3} \cdot$ Giovanna Sarno $^{1,2} \cdot$ Göran Olivecrona $^{4} \cdot$ Ulf Jensen $^{5} \cdot$ Johan Nilsson $^{6}$. \\ Jörg Carlsson ${ }^{7} \cdot$ Stefan James ${ }^{1,2} \cdot$ Bo Lagerqvist $^{1,2}$
}

Received: 6 September 2017 / Accepted: 9 April 2018 / Published online: 17 April 2018

(c) The Author(s) 2018

\begin{abstract}
Objectives Old-generation drug-eluting coronary stents (o-DES) have despite being safe and effective been associated with an increased propensity of late stent thrombosis (ST). We evaluated ST rates in o-DES, new-generation DES (n-DES) and bare metal stents (BMS) the first year $(<1$ year) and beyond 1 year $(>1$ year).

Methods We evaluated all implantations with BMS, o-DES (Cordis Cypher, Boston Scientific Taxus Liberté and Medtronic Endeavor) and n-DES in the Swedish coronary angiography and angioplasty registry (SCAAR) between 1 January 2007 and 8 January 2014 ( $n=207291)$. All cases of ST ( $n=2268)$ until 31 December 2014 were analyzed.

Results The overall risk of ST was lower in both n-DES and o-DES compared with BMS up to 1 year (n-DES versus BMS: adjusted risk ratio (RR) $0.48(0.41-0.58)$ and o-DES versus BMS: $0.56(0.46-0.67)$, both $p<0.001)$. From 1 year after stent implantation and onward, the risk for ST was higher in o-DES compared with BMS [adjusted RR, 1.82 (1.47-2.25], $p<0.001)$. N-DES were associated with similar low ST rates as BMS from 1 year and onward [adjusted RR 1.21 $(0.94-1.56)$, $p=0.135]$.

Conclusion New-generation DES were associated with lower ST rates in comparison to BMS during the first-year poststenting. After 1 year, n-DES and BMS were associated with similar ST rates.

Trial Registration This study was a retrospective observational study and as such did not require clinical trial database registration.
\end{abstract}

Keywords Bare metal stents $\cdot$ Drug-eluting stents $\cdot$ Stent thrombosis $\cdot$ Percutaneous coronary intervention

Varenhorst: Drug-eluting stents and stent thrombosis

Electronic supplementary material The online version of this article (https://doi.org/10.1007/s00392-018-1252-0) contains supplementary material, which is available to authorized users.

Christoph Varenhorst

christoph.varenhorst@medsci.uu.se

1 Uppsala Clinical Research Center, Uppsala University, Uppsala, Sweden

2 Department of Medical Sciences, Cardiology, Uppsala University, Dag Hammarsköldsväg 14B, 75337 Uppsala, Sweden

3 Department of Internal Medicine, Cardiology, Västerås County Hospital, Västerås, Sweden

\section{Introduction}

Percutaneous coronary intervention (PCI) to treat coronary artery disease has become the most frequently performed therapeutic procedure in medicine [1]. Despite the advantage of stenting, the iatrogenic intimal injury from stenting, not seldom produce a neointimal hyperplasia leading to restenosis and a need for a repeat revascularization [2]. Therefore,

4 Department of Cardiology, Lund University, Lund, Sweden

5 Department of Clinical Science and Education, Södersjukhuset, Karolinska Institutet, Stockholm, Sweden

6 Department of Cardiology, Heart Centre, Umeå University, Umeå, Sweden

7 Faculty of Health and Life Sciences, Linnaeus University, Kalmar, Sweden 
drug-eluting stents (DES) coated with antiproliferative agents were developed and demonstrated in randomized trials lower restenosis rates and need for revascularization compared to bare metal stents (BMS) [2-4].

The concern of increased risk of stent thrombosis (ST) with DES, caused by an incomplete neointimal coverage, was raised in the year 2006 after reports from pathoanatomical studies [5], randomized trials [6] and registries [7]. We, therefore, previously evaluated the long-term outcome in all patients who underwent stenting in Sweden between 2003 and 2006 [8, 9]. Compared with bare metal stents, drugeluting stents were associated with a decrease in the rate of restenosis and but importantly a higher risk of stent thrombosis (ST) and mortality [9]. When the analysis was repeated with an extended patient population, where the course of time had led to a gradual change in patient selection for old-generation drug-eluting coronary stents (o-DES) and adjunct antithrombotic treatment, the association between o-DES and mortality disappeared while the association with ST remained [8].

It is generally accepted that late ST is associated with inadequate stent endothelialization [10]. Whilst the exact cause of poor endothelialization has not been completely elucidated, there are theories that challenge the role of coating polymers due to their potential of evoking localized inflammatory responses [11]. New technologies that followed o-DES such as biodegradable drug-eluting coatings, textured stent surfaces for polymer-free drug-stent attachment and drug-filled reservoirs have aimed at improving long-term outcomes by reducing both late ST and restenosis. Furthermore, neointimal atherosclerotic change, or neoatherosclerosis, is rarely reported and most often occurs beyond 5 years. Nakazawa et al. [12] reported in 2011 that incidence of neoatherosclerosis was significantly higher and occurred earlier in DES than in BMS.

In this study, we evaluated all implantations with BMS, o-DES and n-DES in the nation-wide Swedish coronary angiography and angioplasty registry (SCAAR) between 1 January 2007 and 8 January 2014. We calculated the overall risk of ST in n-DES and o-DES compared with BMS up to 1 year (early and late ST) and more than 1 year after implantation (very late ST).

\section{Methods}

This study was a prospective observational cohort study using data from SCAAR (Swedish Coronary Angiography and Angioplasty Register), a part of the SWEDEHEART registry.

The Swedish nation-wide SCAAR registry captures all coronary angiographies and percutaneous coronary interventions in Sweden. Details about the register were described previously [13]. Since 1 March 2004, the webbased electronic case report form requires that information about restenosis in each and every implanted stent is recorded at the time of any subsequent coronary angiography for any clinical indication.

In our study, we analyzed all implantations (> 1000 implanted individual stents) with BMS, o-DES [Cordis Cypher (Sirolimus, PEVA (polyethylene-co-vinyl acetate) Polymer), Boston Scientific Taxus Liberté (Paclitaxel, SIBS (polyethylene-co-vinyl acetate), Polymer and Medtronic Endeavor (Zotarolimus, Phosphorylcoline Polymer, Medtronic, Inc.)] and n-DES [Medtronic Resolute (Zotarolimus, Bio Linx Polymer, Abbot XienceV (Everolimus, Acrcylic/Fluoro Polymer), Abbot Xience Prime (Everolimus, Acrylic/Fluoro Polymer), Boston Promus (Everolimus, PVDF-HFP (polyvinylidenefluoride-hexafluoropropylene) Polymer), Boston Promus Element (Everolimus, PVDF-HFP Polymer), Biosensors Biomatrix (Biolimus A9, polylactic acid polymer)], between 1 January 2007 and 8 January 2014. All cases of definite ST during this time period were analyzed based on type of assigned stent group (BMS, n-DES or o-DES) and antiproliferative drug. The Ethics Committee at Uppsala University approved the study.

Continuous variables were expressed as means and standard deviations and discrete variables as percentages.

The primary objective was to evaluate occurrence of definite ST in BMS, n-DES and o-DES. The secondary objective was to evaluate the occurrence of definite ST in the different DES according to antiproliferative stent drug. The statistical analysis for ST was performed per stent (not per patient). To compensate for the non-randomized design of this study, multivariate adjustment was performed. The adjusted cumulative risk of ST was calculated using the Cox proportional hazard method.

In the model for calculation of the adjusted relative risk, the following variables that could be potential confounders were included: age, gender, diabetes, hypertension, dyslipidemia, smoking status, clinical indication of the procedure, use of acetyl salicylic acid, GPIIb/IIIa and/or P2Y12 receptor inhibitors at the index procedure, treated vessel, previous myocardial infarction (MI), previous coronary artery bypass grafting (CABG), previous PCI, year of the index procedure, enrolling center, lesion type, bifurcation lesions, restenotic lesions, chronic total occlusions (CTO), stent type, stent diameter, stent length, three-vessel/left main disease, the use of additional stents, and maximal inflation pressure. The statistical interaction between the year of the procedure and the type of stent was assessed in the Cox analysis.

To provide separate descriptions of the relative risks of ST up to 1 year (early and late ST) and after 1 year (very late ST), we performed "landmark analyses" with a prespecified landmark set at 12 months. 
All reported $P$ values are two sided. All analyses were performed with the use of SPSS statistical software (version 19.0, SPSS Inc., Chicago, IL, USA).

\section{Results}

During the study period from year 2007 to 2014, a total of 207,291 stents were implanted, of these were 85,583 BMS, 103,075 n-DES and 18,633 o-DES. The distribution of stent types during the observation period is shown in Fig. 1.

The background and procedural characteristics of the patients treated with the stents analyzed are shown in Table 1. Bare metal stents as compared to DES were more likely to have been used in STEMI patients and less likely in patients with previous PCI and diabetes. Within the DES groups (n-DES versus o-DES), there were no major differences in patient and procedural characteristics, except a shift from clopidogrel to ticagrelor before PCI and a less frequent use of GPIIb/IIIa-inhibitors in n-DES compared to o-DES (Table 1).

A total of 2268 cases of ST occurred during the study period. The risk of stent thrombosis was lower in DES (both n-DES and o-DES) compared to BMS up to 1 year (DES versus BMS: adjusted risk ratio (RR) [0.51 (0.45-0.59) $p<0.001]$ \} but for ST \{from 1 year and onward the risk of ST was higher with DES than with BMS [DES versus BMS: (1.55 (1.28-1.87) $p<0.001)]\}$ (Fig. 2).
The overall risk of ST was lower in both n-DES $(n=103$ $075)$ and o-DES ( $n=18633)$ compared with BMS $(n=85$ 583 ) up to 1 year [n-DES versus BMS: adjusted risk ratio (RR) $0.48(0.41-0.58)$ and o-DES versus BMS: 0.56 (0.46-0.67), both $p<0.001]$ (Fig. 3; Table 2).

From 1 year after stent implantation and onward, the risk for ST was higher in o-DES $(n=17$ 300) compared with BMS ( $n=74228)$ [adjusted RR, 1.82 (1.47-2.25), $p<0.001]$. New-generation DES $(n=69250)$ were associated with similar low ST rates as BMS from 1 year and onward [adjusted RR $1.21(0.94-1.56), p=0.135$ ].

Compared to o-DES, n-DES showed a lower risk for stent thrombosis both up to 1 year [adjusted RR 0.87 $(0.69-1.09), p=0.232$ ] and from 1 year onwards [adjusted RR 0.67 (0.51-0.87), $p=0.003$ ] (Fig. 3; Table 2).

We performed a sensitivity analysis omitting the Endeavor zotarolimus-eluting stent from the n-DES group with similar results to the main analysis (Supplemental Table 1).

When we analyzed ST rates in stents according to drug coating, both sirolimus- and paclitaxel-coated stents were associated with higher stent thrombosis rates from 1 year and onward compared to BMS [adjusted RR 2.00 (1.41-2.83) and 1.54 (1.14-2.08) for sirolimus and paclitaxel, respectively]. During the first year, both sirolimusand paclitaxel-coated stents were associated with lower ST rates than BMS. Everolimus-, zotarolimus- and biolimuscoated stents were associated with lower ST rates both up to 1 year and from 1 year and onward (Fig. 4; Table 3).
Fig. 1 Distribution of the implanted stents: bare metal, new- and old-generation stents during study period

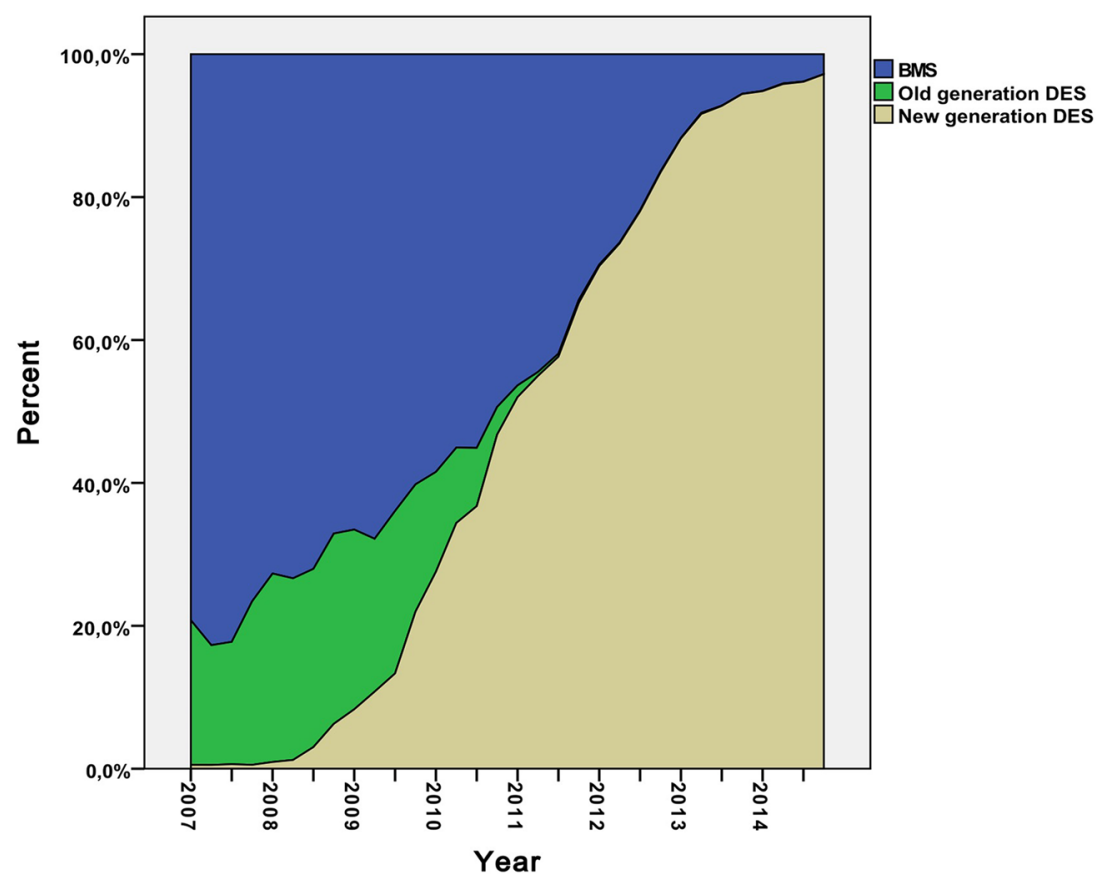


Table 1 Baseline and procedural characteristics for stent groups treated with bare metal stents, new- and oldgeneration stents

\begin{tabular}{|c|c|c|c|}
\hline Variable (n \%) & BMS $(n=85,583)$ & $\mathrm{n}$-DES $(n=103,075)$ & o-DES $(n=18,633)$ \\
\hline Women & $23,355(27.3)$ & $25,387(24.6)$ & $4901(26.3)$ \\
\hline Age, yrs & $67.9 \pm 11$ & $67.2 \pm 10.7$ & $66.0 \pm 10.4$ \\
\hline \multicolumn{4}{|l|}{ Indication for the procedure } \\
\hline Stable angina & $15,705(18.4)$ & $29,605(28.7)$ & $6534(35.1)$ \\
\hline ST-elevation MI & $28,395(33.2)$ & $19,134(18.6)$ & $2084(11.2)$ \\
\hline Non-ST-elevation MI/unstable angina & $39,024(45.6)$ & $51,375(49.8)$ & $9640(51.7)$ \\
\hline \multicolumn{4}{|l|}{ Coexisting conditions } \\
\hline Hypertension & $46,113(53.9)$ & $66,999(65.0)$ & $11,571(62.1)$ \\
\hline Diabetes mellitus & $13,901(16.2)$ & $24,042(23.3)$ & $5215(28.0)$ \\
\hline Hypercholesterolemia & $39,759(46.5)$ & $59,814(58.0)$ & $12,295(66.0)$ \\
\hline Smoker status: current & $18,140(21.2)$ & $18,326(17.8)$ & $2744(14.7)$ \\
\hline Smoker status: former $>1$ month & $29,360(34.4)$ & $40,321(39.1)$ & $7250(38.9)$ \\
\hline Previous MI & $20,209(23.6)$ & $31,744(30.8)$ & 7195 (38.6) \\
\hline Previous PCI & $16,051(18.8)$ & $32,313(31.3)$ & $7844(42.1)$ \\
\hline Previous CABG & $7253(8.5)$ & $11,095(10.8)$ & $2832(15.2)$ \\
\hline \multicolumn{4}{|l|}{ Procedural characteristics } \\
\hline No. of stents per procedure & $1.88 \pm 1.07$ & $2.25 \pm 1.3$ & $2.24 \pm 1.25$ \\
\hline Stent diameter $(\mathrm{mm})$ & $3.1 \pm 0.53$ & $2,97 \pm 0.52$ & $2.7 \pm 0.50$ \\
\hline Total stent length (mm) & $17.0 \pm 5.6$ & $20.1 \pm 7.7$ & $19.2 \pm 7.1$ \\
\hline Treated vessel: RCA & $30,617(35.8)$ & $29,061(28.2)$ & $4788(25.7)$ \\
\hline Treated vessel: left main & $1158(1.4)$ & $3544(3.4)$ & $653(3.5)$ \\
\hline Treated vessel: LAD & $32,945(38.5)$ & $45,238(43.9)$ & $8260(44.3)$ \\
\hline Treated vessel: LCX & $18,370(21.5)$ & $22,381(21.7)$ & $4061(21.8)$ \\
\hline Treated vessel: CABG graft & $2493(2.9)$ & $2851(2.8)$ & $871(4.7)$ \\
\hline Bifurcation lesion & $6611(7.7)$ & $13,532(13.1)$ & $2556(13.7)$ \\
\hline Three-vessel disease & 16,965 (19.8) & $21,224(20.6)$ & $4060(21.8)$ \\
\hline \multicolumn{4}{|l|}{ Medications before PCI } \\
\hline ASA & 78,387 (91.6) & $97,661(94.7)$ & $17,911(96.1)$ \\
\hline Clopidogrel & $67,707(79.1)$ & $53,609(52.0)$ & $16,099(86.4)$ \\
\hline Ticagrelor & $4631(5.4)$ & $41,347(40.1)$ & $32(0.2)$ \\
\hline Prasugrel & $3010(3.5)$ & $4707(4.6)$ & $81(0.4)$ \\
\hline \multicolumn{4}{|l|}{ Medications under PCI } \\
\hline GP IIb/IIIa & $17,529(20.5)$ & $6235(6.0)$ & $2248(12.1)$ \\
\hline Heparin & $50,617(59.1)$ & $71,090(69.0)$ & $13,186(70.8)$ \\
\hline LMWH & 7949 (9.3) & $5554(5.4)$ & $1621(8.7)$ \\
\hline Bivalirudin & $25,904(30.3)$ & $25,574(24.8)$ & 3625 (19.5) \\
\hline
\end{tabular}

Values are $N(\%)$ or mean $\pm \mathrm{SD}$

$B M S$ bare metal stent, $n$-DES new-generation drug-eluting stent, $o-D E S$ old-generation drug-eluting stent, $M I$ myocardial infarction, $C A B G$ coronary artery bypass grafting, PCIpercutaneous coronary stenting, $A S A$ acetylsalicylic acid, $G P$ glycoprotein, $L A D$ left anterior descending artery, $L C X$ left circumflex artery, $L M W H$ low molecular weight heparin, $P C I$ percutaneous coronary intervention, $R C A$ right coronary artery

\section{Discussion}

In this study, we report from a large cohort of unselected consecutive patients treated with coronary stents at all interventional centers in Sweden that n-DES are associated with reduced ST rates during the first year after implantation. Importantly, in contrast to o-DES, n-DES were not associated with higher very late ST rates after 1 year compared to BMS. This benefit compared to BMS and o-DES, seemed to be maintained during the follow-up period of up to 5 years. This non-randomized comparison between the stent types was adjusted for all available confounders but there is always a possibility of selection bias because of unknown confounders. Nonetheless, the reliability of our results is strengthened by the fact that all ST cases have been angiographically assessed, registry source-data verification (showing a 95\% correspondence with patients' hospital records) and the use of definite, angiographically proven ST and not Academic 


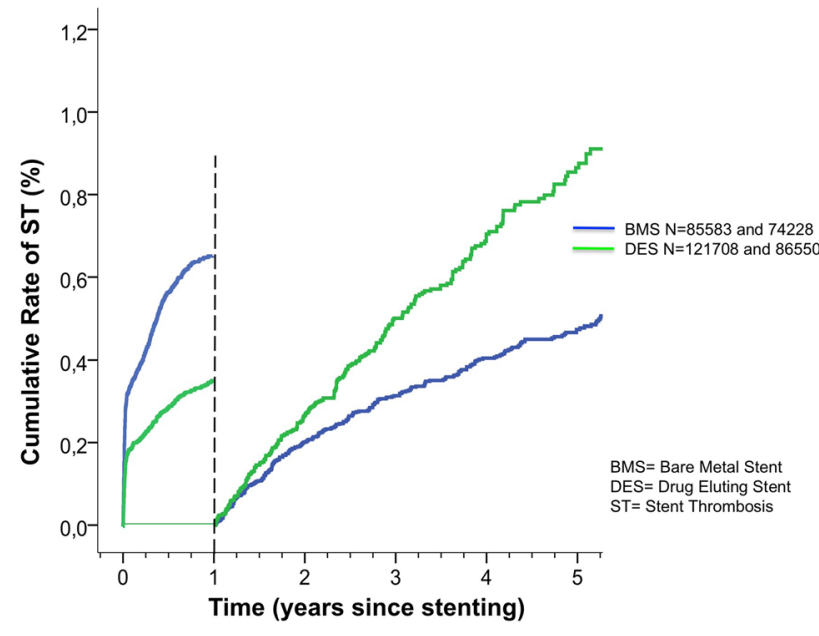

Fig. 2 Cumulative rate of stent thrombosis (unadjusted) in bare metal and drug-eluting stents implanted



Fig. 3 Cumulative rate of stent thrombosis (unadjusted) in bare metal, new- and old-generation stents

Table 2 Adjusted risk ratios for stent thrombosis in bare metal stents, new-generation and old-generation drug-eluting stents

\section{Definite ST up to 1 year Definite ST} from 1 year and onward

\begin{tabular}{lll}
\hline o-DES versus BMS & $0.56(0.46-0.67)^{*}$ & $1.82(1.47-2.25)^{*}$ \\
n-DES versus BMS & $0.48(0.41-0.58)^{*}$ & $1.21(0.94-1.56)$ \\
n-DES versus o-DES & $0.87(0.69-1.09)$ & $0.67(0.51-0.87)^{*}$ \\
\hline
\end{tabular}

Risk ratios and $95 \%$ confidence intervals for definite stent thrombosis $o$-DES old-generation drug-eluting stents, $n$-DES new-generation drug-eluting stents, $B M S$ bare metal stents, $S T$ stent thrombosis

*Significant comparisons $(p<0.05)$

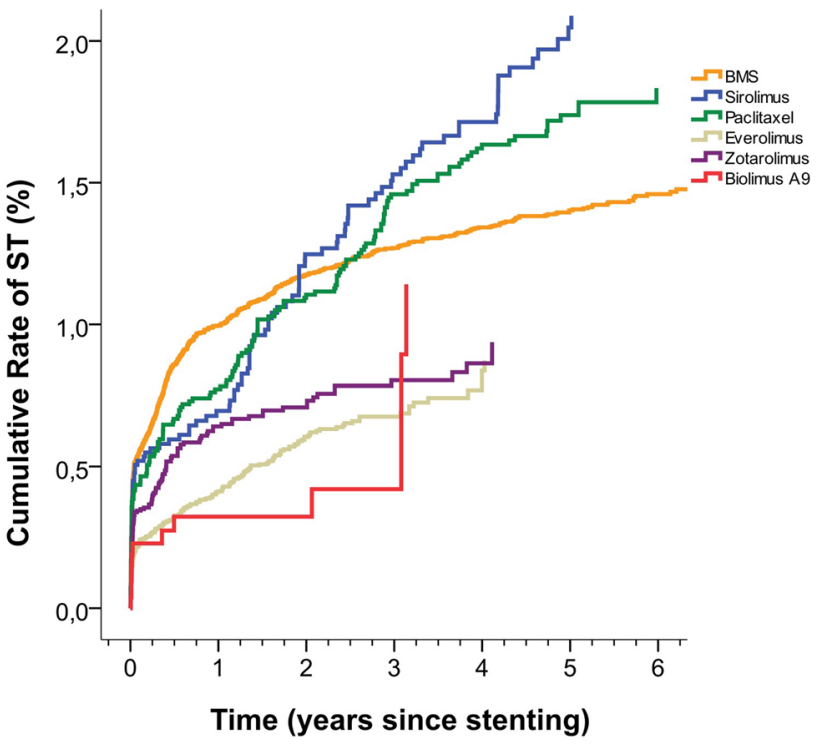

Fig. 4 Cumulative rate of stent thrombosis (adjusted) in bare metal stents and drug-eluting stents according to different stent drugs

Table 3 Adjusted risk ratios for stent thrombosis in bare metal stents versus drug-eluting stents according to drug-eluting stent drug

\begin{tabular}{|c|c|c|}
\hline & $\begin{array}{l}\text { Definite ST up to } \\
1 \text { year }\end{array}$ & $\begin{array}{l}\text { Definite ST from } \\
1 \text { year and onward }\end{array}$ \\
\hline Sirolimus versus BMS & $0.71(0.53-0.95)^{*}$ & $2.00(1.41-2.83)^{*}$ \\
\hline Paclitaxel versus BMS & $0.78(0.61-0.98)^{*}$ & $1.54(1.14-2.08)^{*}$ \\
\hline $\begin{array}{l}\text { Everolimus versus } \\
\text { BMS }\end{array}$ & $0.41(0.35-0.48)^{*}$ & $1.05(0.76-1.46)$ \\
\hline $\begin{array}{l}\text { Zotarolimus versus } \\
\text { BMS }\end{array}$ & $0.64(0.52-0.77)^{*}$ & $0.84(0.55-1.29)$ \\
\hline Biolimus versus BMS & $0.33(0.17-0.67)^{*}$ & $1.12(0.39-3.24)$ \\
\hline
\end{tabular}

Risk ratios and $95 \%$ confidence intervals for definite stent thrombosis $B M S$ bare metal stents, $S T$ stent thrombosis

*Significant comparisons $(p<0.05)$

Research Consortium (ARC) probable/possible ST as the only endpoint measure.

The technical development of DES has aimed at reducing the trade-off between delayed coronary vessel healing and restenosis, both of which contribute to stent thrombosis risk. New-generation DES as compared to o-DES have thinner polymer, reduced strut thickness and alternative drugs that may modulate the long-term risk of ST [14-18].

Most of the n-DES received CE (conformité européenne) mark approval based on results from non-inferiority trials compared with o-DES $[19,20]$. Although not individually powered to show differences in ST, recent data from direct comparisons between zotarolimus-eluting and everolimuseluting stents have demonstrated similar safety and efficacy throughout 4 years [21, 22]. Furthermore, a pooled 
analysis of two trials evaluating BMS versus cobalt-chromium everolimus-eluting or biolimus A9-eluting stents showed a reduced risk of definite ST up to 1 year compared to BMS [23-25]. In a randomized, single-blind, non-inferiority study comparing a bioabsorbable polymer everolimuseluting stent with an everolimus-coated stent, rates of ST and target lesion failure at 1 year were similar [15]. In a large network metaanalysis by Palmerini et al. [26], including fifty-one trials and 52,158 patients with a median follow-up of 3.8 years, n-DES showed improved safety as compared to o-DES.

The risk of ST is strongly determined by antiplatelet drug response, duration of antiplatelet therapy, burden of cardiovascular risk and technical factors that influence the success of coronary stent implantation $[27,28]$. In acute coronary syndrome (ACS) patients, both prasugrel and ticagrelor have demonstrated greater efficacy in preventing ST compared to clopidogrel $[29,30]$. During the time period of the present study, a shift from clopidogrel to ticagrelor as the most widely used P2Y12-receptor antagonist in the treatment of ACS in Sweden occurred [31]. In this study, also beyond the standard and in Sweden widely used dual antiplatelet treatment duration post-ACS of 1 year, we showed that n-DES were associated with lower rates of ST ( $>1$ year) compared to BMS. Also in patients with more complex coronary artery disease (SYNTAX score > 11 vs. $\leq 11$ ) recent data from four all-comer trials showed improved clinical outcomes, including reduced ST rates, with n-DES as compared to o-DES [32]. In the recently published Norwegian Coronary Stent Trial (NORSTENT), lower rates of repeat revascularization but no difference in death or nonfatal spontaneous MI rates were shown in patients receiving DES as compared to BMS [33]. Interestingly, overall rates of definite ST at 6-year follow-up was similar to those in our study and also appeared to be lower in DES compared to BMS patients [0.8\% for DES and $1.2 \%$ for BMS $(p=0.0498)]$. The majority of DES implanted were everolimus ( $82.9 \%$ ) followed by zotarolimus (13.1\%) eluting and no o-DES were implanted. The results support our finding of a long-term durability of improved outcomes with new-generation drug-eluting stents.

\section{Limitations}

Despite the use of statistical adjustments, differences in baseline characteristics or selection criteria that might not have been recorded could remain and influence the results. Also, changes in event rates over time could have been influenced by the smaller number of patients with drug-eluting stents early in the study period. The analysis of ST according to antiproliferative agent is limited by the fact that differences between stents are based on all three components of the stent (i.e., backbone, coating and antiproliferative agent).
The database did not contain information on the duration and type of the antiplatelet treatment. Therefore, data for the first year are less reliable also due to the fact that the indication for the index procedure (stable versus acute indication) and antithrombotic treatment could influence ST rates.

\section{Conclusions}

In this large study of 207,291 stents with complete long-term follow-up, new-generation DES were associated with ST rates compared to BMS up to 1 year and after 1 year (very late ST) compared to old-generation DES. Our results are consistent with the previous report on n-DES from SCAAR $[34,35]$ and confirm a higher performance of n-DES in an even larger population and a longer follow-up.

Acknowledgements We would like to thank all the participating hospitals for contributing with data to the SWEDEHEART register.

Author contributions All authors contributed to study design and interpretation of results, and reviewed and approved the manuscript prior to submission. C.V. wrote the first manuscript draft. B.L. performed all statistical analyses. No stent manufacturer had any role in the study.

Funding This study was funded by Uppsala Clinical Research Center.

Conflict of interest C.V. reports during the conduct of this work, institutional research grants from AstraZeneca and The Medicines Company, lecture and advisory board fees from AstraZeneca, The Medicines Company and Boeringer Ingelheim, lecture fees from Bayer, CSL Behring, Bristol Myers Squibb, and Pfizer and is on the Clinical Endpoint Committee for Pfizer, Bristol Myers Squibb, Philips and AstraZeneca. At the time of resubmission of a revised version of this manuscript C.V reports being a Pfizer employee. M.L. reports no conflicts of interest. G.S. reports institutional research grant from Boston Scientific. G.O. reports physician proctor for Edwards Lifesciences and EPS Vascular, lecture fees from Biotronik, BBraun, advisory board fees for Vascular Solutions and is on the Clinical Endpoint Committee for Biosensors. U.J reports no conflicts of interest. J.N. reports no conflicts of interest. J.C. reports lecture fees from BBraun. S.J. reports institutional research grants and honoraria from Boston Scientific, Abbot vascular and Biotronic. B.L reports institutional grant from AstraZeneca.

Open Access This article is distributed under the terms of the Creative Commons Attribution 4.0 International License (http://creativeco mmons.org/licenses/by/4.0/), which permits unrestricted use, distribution, and reproduction in any medium, provided you give appropriate credit to the original author(s) and the source, provide a link to the Creative Commons license, and indicate if changes were made.

\section{References}

1. Nabel EG, Braunwald E (2012) A tale of coronary artery disease and myocardial infarction. N Engl J Med 366:54-63

2. Stefanini GG, Holmes DR Jr. (2013) Drug-eluting coronary-artery stents. N Engl J Med 368:254-265 
3. Stone GW, Ellis SG, Cox DA, Hermiller J, O'Shaughnessy C, Mann JT, Turco M, Caputo R, Bergin P, Greenberg J, Popma JJ, Russell ME, Investigators T-I (2004) A polymer-based, paclitaxeleluting stent in patients with coronary artery disease. N Engl J Med 350:221-231

4. Moses JW, Leon MB, Popma JJ, Fitzgerald PJ, Holmes DR, O'Shaughnessy C, Caputo RP, Kereiakes DJ, Williams DO, Teirstein PS, Jaeger JL, Kuntz RE, Investigators S (2003) Sirolimus-eluting stents versus standard stents in patients with stenosis in a native coronary artery. N Engl J Med 349:1315-1323

5. Virmani R, Guagliumi G, Farb A, Musumeci G, Grieco N, Motta T, Mihalcsik L, Tespili M, Valsecchi O, Kolodgie FD (2004) Localized hypersensitivity and late coronary thrombosis secondary to a sirolimus-eluting stent: should we be cautious? Circulation 109:701-705

6. Bavry AA, Kumbhani DJ, Helton TJ, Borek PP, Mood GR, Bhatt DL (2006) Late thrombosis of drug-eluting stents: a meta-analysis of randomized clinical trials. Am J Med 119:1056-1061

7. Daemen J, Wenaweser P, Tsuchida K, Abrecht L, Vaina S, Morger C, Kukreja N, Juni P, Sianos G, Hellige G, van Domburg RT, Hess OM, Boersma E, Meier B, Windecker S, Serruys PW (2007) Early and late coronary stent thrombosis of sirolimus-eluting and paclitaxel-eluting stents in routine clinical practice: data from a large two-institutional cohort study. Lancet 369:667-678

8. Lagerqvist B, James SK, Stenestrand U, Lindback J, Nilsson T, Wallentin L, Group SS (2007) Long-term outcomes with drugeluting stents versus bare-metal stents in Sweden. N Engl J Med 356:1009-1019

9. James SK, Stenestrand U, Lindback J, Carlsson J, Schersten F, Nilsson T, Wallentin L, Lagerqvist B, Group SS (2009) Longterm safety and efficacy of drug-eluting versus bare-metal stents in Sweden. N Engl J Med 360:1933-1945

10. O’Brien B, Zafar H, Ibrahim A, Zafar J, Sharif F (2016) Coronary stent materials and coatings: a technology and performance update. Ann Biomed Eng 44:523-535

11. Nakazawa G (2011) Stent thrombosis of drug eluting stent: pathological perspective. J Cardiol 58:84-91

12. Nakazawa G, Otsuka F, Nakano M, Vorpahl M, Yazdani SK, Ladich E, Kolodgie FD, Finn AV, Virmani R (2011) The pathology of neoatherosclerosis in human coronary implants bare-metal and drug-eluting stents. J Am Coll Cardiol 57:1314-1322

13. Jernberg T, Attebring MF, Hambraeus K, Ivert T, James S, Jeppsson A, Lagerqvist B, Lindahl B, Stenestrand U, Wallentin L (2010) The Swedish web-system for enhancement and development of evidence-based care in heart disease evaluated according to recommended therapies (SWEDEHEART). Heart 96:1617-1621

14. Meredith IT, Teirstein PS, Bouchard A, Carrie D, Mollmann H, Oldroyd KG, Hall J, Allocco DJ, Dawkins KD, Stone GW (2014) Three-year results comparing platinum-chromium PROMUS element and cobalt-chromium XIENCE V everolimus-eluting stents in de novo coronary artery narrowing (from the PLATINUM Trial). Am J Cardiol 113:1117-1123

15. Kereiakes DJ, Meredith IT, Windecker S, Lee Jobe R, Mehta SR, Sarembock IJ, Feldman RL, Stein B, Dubois C, Grady T, Saito S, Kimura T, Christen T, Allocco DJ, Dawkins KD (2015) Efficacy and safety of a novel bioabsorbable polymer-coated, everolimuseluting coronary stent: the EVOLVE II Randomized Trial. Circ Cardiovasc Interv 8 e002372

16. Danzi GB, Piccolo R, Chevalier B, Urban P, Fath-Ordoubadi F, Carrie D, Wiemer M, Serra A, Wijns W, Kala P, Stabile A, Goicolea Ruigomez J, Sagic D, Laanmets P, Strupp G, West N, Nobori I (2016) Five-year clinical performance of a biodegradable polymer-coated biolimus-eluting stent in unselected patients. Heart

17. Saito S, Valdes-Chavarri M, Richardt G, Moreno R, Iniguez Romo A, Barbato E, Carrie D, Ando K, Merkely B, Kornowski
R, Eltchaninoff H, James S, Wijns W, Investigators CI (2014) A randomized, prospective, intercontinental evaluation of a bioresorbable polymer sirolimus-eluting coronary stent system: the CENTURY II (Clinical evaluation of new terumo drug-eluting coronary stent system in the treatment of patients with coronary artery disease) trial. Eur Heart J 35:2021-2031

18. Cassese S, Kufner S, Xhepa E, Byrne RA, Kreutzer J, Ibrahim T, Tiroch K, Valgimigli M, Tolg R, Fusaro M, Schunkert H, Laugwitz KL, Mehilli J, Kastrati A (2016) Three-year efficacy and safety of new- versus early-generation drug-eluting stents for unprotected left main coronary artery disease insights from the ISAR-LEFT MAIN and ISAR-LEFT MAIN 2 trials. Clin Res Cardiol 105:575-584

19. Jensen LO, Thayssen P, Hansen HS, Christiansen EH, Tilsted HH, Krusell LR, Villadsen AB, Junker A, Hansen KN, Kaltoft A, Maeng M, Pedersen KE, Kristensen SD, Botker HE, Ravkilde J, Sanchez R, Aaroe J, Madsen M, Sorensen HT, Thuesen L, Lassen JF, Scandinavian Organization for Randomized Trials With Clinical Outcome IVI (2012) Randomized comparison of everolimus-eluting and sirolimus-eluting stents in patients treated with percutaneous coronary intervention: the scandinavian organization for randomized trials with clinical outcome IV (SORT OUT IV). Circulation 125:1246-1255

20. Kedhi E, Joesoef KS, McFadden E, Wassing J, van Mieghem C, Goedhart D, Smits PC (2010) Second-generation everolimuseluting and paclitaxel-eluting stents in real-life practice (COMPARE): a randomised trial. Lancet 375:201-209

21. Serruys PW, Silber S, Garg S, van Geuns RJ, Richardt G, Buszman PE, Kelbaek H, van Boven AJ, Hofma SH, Linke A, Klauss V, Wijns W, Macaya C, Garot P, DiMario C, Manoharan G, Kornowski R, Ischinger T, Bartorelli A, Ronden J, Bressers M, Gobbens P, Negoita M, van Leeuwen F, Windecker S (2010) Comparison of zotarolimus-eluting and everolimus-eluting coronary stents. N Engl J Med 363:136-146

22. Taniwaki M, Stefanini GG, Silber S, Richardt G, Vranckx P, Serruys PW, Buszman PE, Kelbaek H, Windecker S, Investigators RA-C (2014) 4-year clinical outcomes and predictors of repeat revascularization in patients treated with new-generation drug-eluting stents: a report from the RESOLUTE All-Comers trial (A Randomized Comparison of a Zotarolimus-Eluting Stent with an Everolimus-Eluting Stent for Percutaneous Coronary Intervention). J Am Coll Cardiol 63:1617-1625

23. Sabate M, Cequier A, Iniguez A, Serra A, Hernandez-Antolin R, Mainar V, Valgimigli M, Tespili M, den Heijer P, Bethencourt A, Vazquez N, Gomez-Hospital JA, Baz JA, Martin-Yuste V, van Geuns RJ, Alfonso F, Bordes P, Tebaldi M, Masotti M, Silvestro A, Backx B, Brugaletta S, van Es GA, Serruys PW (2012) Everolimus-eluting stent versus bare-metal stent in ST-segment elevation myocardial infarction (EXAMINATION): 1 year results of a randomised controlled trial. Lancet 380:1482-1490

24. Raber L, Kelbaek H, Ostojic M, Baumbach A, Heg D, Tuller D, von Birgelen C, Roffi M, Moschovitis A, Khattab AA, Wenaweser P, Bonvini R, Pedrazzini G, Kornowski R, Weber K, Trelle S, Luscher TF, Taniwaki M, Matter CM, Meier B, Juni P, Windecker S, Investigators CAT (2012) Effect of biolimuseluting stents with biodegradable polymer vs bare-metal stents on cardiovascular events among patients with acute myocardial infarction: the COMFORTABLE AMI randomized trial. JAMA 308:777-787

25. Sabate M, Raber L, Heg D, Brugaletta S, Kelbaek H, Cequier A, Ostojic M, Iniguez A, Tuller D, Serra A, Baumbach A, von Birgelen C, Hernandez-Antolin R, Roffi M, Mainar V, Valgimigli M, Serruys PW, Juni P, Windecker S (2014) Comparison of newergeneration drug-eluting with bare-metal stents in patients with acute ST-segment elevation myocardial infarction: a pooled analysis of the EXAMINATION (clinical Evaluation of the Xience-V 
stent in Acute Myocardial INfArcTION) and COMFORTABLEAMI (Comparison of Biolimus Eluted From an Erodible Stent Coating With Bare Metal Stents in Acute ST-Elevation Myocardial Infarction) trials. JACC Cardiovasc Interv 7:55-63

26. Palmerini T, Benedetto U, Biondi-Zoccai G, Della Riva D, Bacchi-Reggiani L, Smits PC, Vlachojannis GJ, Jensen LO, Christiansen EH, Berencsi K, Valgimigli M, Orlandi C, Petrou M, Rapezzi C, Stone GW (2015) Long-term safety of drug-eluting and bare-metal stents: evidence from a comprehensive network meta-analysis. J Am Coll Cardiol 65:2496-2507

27. Holmes DR Jr, Kereiakes DJ, Garg S, Serruys PW, Dehmer GJ, Ellis SG, Williams DO, Kimura T, Moliterno DJ (2010) Stent thrombosis. J Am Coll Cardiol 56:1357-1365

28. Lee SY, Hong MK, Shin DH, Kim JS, Kim BK, Ko YG, Choi D, Jang Y, Kim HS, Valgimigli M, Palmerini T, Stone GW (2017) Clinical outcomes of dual antiplatelet therapy after implantation of drug-eluting stents in patients with different cardiovascular risk factors. Clin Res Cardiol 106:165-173

29. Wiviott SD, Braunwald E, McCabe CH, Montalescot G, Ruzyllo W, Gottlieb S, Neumann FJ, Ardissino D, De Servi S, Murphy SA, Riesmeyer J, Weerakkody G, Gibson CM, Antman EM, Investigators T-T (2007) Prasugrel versus clopidogrel in patients with acute coronary syndromes. N Engl J Med 357:2001-2015

30. Wallentin L, Becker RC, Budaj A, Cannon CP, Emanuelsson H, Held C, Horrow J, Husted S, James S, Katus H, Mahaffey KW, Scirica BM, Skene A, Steg PG, Storey RF, Harrington RA, Investigators P, Freij A, Thorsen M (2009) Ticagrelor versus clopidogrel in patients with acute coronary syndromes. N Engl J Med 361:1045-1057

31. Sahlen A, Varenhorst C, Lagerqvist B, Renlund H, Wallentin L, James SK, Jernberg T (2016) Contemporary use of ticagrelor in patients with acute coronary syndrome: insights from Swedish Web System for Enhancement and Development of EvidenceBased Care in Heart Disease Evaluated According to Recommended Therapies (SWEDEHEART). Eur Heart J Cardiovasc Pharmacother 2:5-12

32. Piccolo R, Pilgrim T, Heg D, Franzone A, Rat-Wirtzler J, Raber L, Silber S, Serruys PW, Juni P, Windecker S (2015) Comparative effectiveness and safety of new-generation versus early-generation drug-eluting stents according to complexity of coronary artery disease: a patient-level pooled analysis of 6,081 Patients. JACC Cardiovasc Interv 8:1657-1666

33. Bonaa KH, Mannsverk J, Wiseth R, Aaberge L, Myreng Y, Nygard O, Nilsen DW, Klow NE, Uchto M, Trovik T, Bendz B, Stavnes S, Bjornerheim R, Larsen AI, Slette M, Steigen T, Jakobsen OJ, Bleie O, Fossum E, Hanssen TA, Dahl-Eriksen O, Njolstad I, Rasmussen K, Wilsgaard T, Nordrehaug JE, Investigators N (2016) Drug-eluting or bare-metal stents for coronary artery disease. $\mathrm{N}$ Engl J Med 375:1242-1252

34. Sarno G, Lagerqvist B, Frobert O, Nilsson J, Olivecrona G, Omerovic E, Saleh N, Venetzanos D, James S (2012) Lower risk of stent thrombosis and restenosis with unrestricted use of 'new-generation' drug-eluting stents: a report from the nationwide Swedish Coronary Angiography and Angioplasty Registry (SCAAR). Eur Heart J 33:606-613

35. Sarno G, Lagerqvist B, Nilsson J, Frobert O, Hambraeus K, Varenhorst C, Jensen UJ, Todt T, Gotberg M, James SK (2014) Stent thrombosis in new-generation drug-eluting stents in patients with STEMI undergoing primary PCI: a report from SCAAR. J Am Coll Cardiol 64:16-24 